\title{
Criminal Responsibility For Criminal Followers Producing And Selling "Drinks" White Alcohol / White Liquor In The Legal Area Of Kudus Police
}

\author{
Hendro Santiko ${ }^{1}$ and Akhmad Khisni ${ }^{2}$
}

Abstract. This research wants to answer the problem. How is law enforcement against criminal offenders producing and selling "White Alcohol/ White Liquor" in the Kudus police area? and criminal liability against criminal offenders producing and selling "White Alcohol/ White Liquor" in the area of the Kudus Police District and in the future?

Based on the results of the study concluded that 2 (two) methods of law enforcement on the circulation of alcohol by the Kudus Police District, namely preventive and repressive.Criminal accountability against criminal offenders producing and selling "White Alcohol/ White Liquor" in the area of the Kudus Police in eradicating opaque liquor in the Kudus Police Region, Obstacles faced by the Kudus Police Sabhara Unit are relating to the limited number of members of the Kudus Police Sabhara unit that generally still unsatisfactory, not yet maximized and the evenly distributed socialization steps of the Regional Government Regulation carried out at the community level, so far it is not uncommon for insufficient understanding of procedures or systems at the time of preparation up to the enactment of Perda Sabhara Unit of the Kudus Police Unit in eradicating liquor oplosan in the Kudus Police District Region,criminal liability against criminal offenders producing and selling "White Alcohol/ White Liquor" that will come in the renewal of Indonesian criminal is done by providing guidance, advising or guiding so as not to repeat the mistakes that have been made namely violating local regulations.

Keywords: Criminal Liability; Criminals; Producing and Selling White Alcohol/ White Liquor.

\section{Introduction}

Social problems in the midst of society are always changing and will continue to develop following where the community itself. There is no exception to the people of Kudus which is a religious, guardian city, safe, orderly and calm. This can be seen from the number of Islamic boarding schools spread in the Kudus. However, order and comfort are troubled by the rampant circulation and seller of White Alcohol/ White Liquor beverages among the people.

The development of the world is growing rapidly and has begun to enter the era of globalization which forces people to think and change lives to follow the global economy. Globalization causes all developed countries to compete to form a developed economy. Communities to meet the necessities of life, compete with each other and compete to meet their economic needs. This triggers people to think quickly to get money quickly to make ends meet. One way to do this is by trading or selling, through trade the public can benefit from the goods / services offered.

Alcoholic drinks are one of the problems in Indonesia. Alcohol, if consumed in excessive

1 Student of Master of Law, Sultan Agung Islamic University (UNISSULA), Semarang, email: nur.umroh02@gmail.com

${ }^{2}$ Lecturer of Master of Law, Sultan Agung Islamic University (UNISSULA), Semarang 
amounts, can cause disease. These include swollen liver, brain damage, decreased sensory function, fetal defects, liver cancer, digestive system damage, negative hormonal effects, and over dosage. The rampant circulation of liquor which is often uncontrolled in the community requires special attention especially the legal aspect as a tool to regulate public relations.

Kudus already has a Regent Regulation Number 17 of 2005 concerning Implementing Regional Regulations of Kudus Number 12 of 2004 concerning zero percent alcoholic drinks that have not been optimal. In a number of places, liquor vendors are still operating surreptitiously, to supervise and control the distribution of illegal liquor in the Kudus area. There are many naughty sellers who dare to sell liquor with various brands. These alcoholic sellers and dealers feel unafraid of the threat of punishment as stated in Regional Regulation No. 12 of 2004 concerning Alcoholic Beverages. The civil service police unit (Satpol PP) and the police have also tried to overcome it by arresting and even eradicating the distribution of illegal alcohol in accordance with the rules in taking action. This activity was carried out in order to create an orderly Kudus from the circulation of liquor.

Criminal cases of goods who sell, offer, deliver, offer or distribute goods that are known to endanger the lives or health of people, while the dangerous nature is not notified, business actors are prohibited from producing and or trading goods that do not include an expiry date and do not put labels, business actors food that intentionally does not have a marketing authorization for any processed food that is made domestically or imported to be traded in retail packaging, business actors conducting trade business activities granted by the Minister as intended in Article 204 (1) of the Criminal Code Article 62 Jo Article 8 paragraph (1) letter g, Act Number 8 of 1999 concerning consumer protection, Article 142 Act Number 18 of 2012 concerning food,Article 106 of Act No. 7 of 2014 concerning Trade occurring on Monday the $16^{\text {th }}$ April 2018 at the warehouse where the production of alcoholic beverages of White Alcohol having the address at Prambat Lor Village, Kaliwungu District, Kudus .

Based on the above background, the authors formulated three problem formulations, namely How is law enforcement against perpetrators of criminal acts producing and selling "White Alcohol/ White Liquor" in the Kudus Police District area? And criminal liability against criminal offenders producing and selling "White Alcohol/ White Liquor" in the area of the Kudus Police Precinct? As well as criminal liability against the perpetrators of criminal acts producing and selling "White Alcohol/ White Liquor" that will come in the renewal of Indonesian criminal.

\section{Research Methods}

The research method used is empirical research and the approaches used are: a Legislative Approach, Conceptual Approach, Sociological Approach. Types of legal materials used: Primary Legal Materials, Secondary Legal Materials and Tertiary Legal Materials obtained through literature study as well as data obtained from related parties. The techniques or methods of collecting legal materials used are: a). Interview with a verbal process where two or more people face each other physically. In the interview process there are two parties occupying different positions, one party functions as an information seeker or questioner or is called an interviewer, while the 
other party functions as a provider of information by the informant and the respondent or perpetrator. In this compilation, the author is the interviewer and the respondent is the criminal and law enforcer. b). Library Studies by means of documentary studies as well. The method used is qualitative analysis, namely: data obtained through field research and library research are then systematically compiled, and subsequently analyzed qualitatively to achieve clarity of the problem to be discussed. The data is then interpretatively analyzed using the theory and positive law that has been poured then deductively drawn conclusions to answer the existing problems.

\section{Results And Discussion}

\subsection{What is the Law Enforcement of Criminal Actors in Producing and Selling "White Alcohol/White Liquor" Beverages in the Kudus Police District Region?}

The police are one of the legal apparatus who work under the auspices of the Indonesian National Police (Indonesian National Police). The function of the Indonesian National Police can be seen in the 1945 Constitution article 30 paragraph (4): "The National Police of the Republic of Indonesia as a state tool that guarantees the security and order of the community is tasked with protecting, protecting, serving the community and enforcing the law".

From this article it is very clear that the priority in carrying out the tasks of the police is in law enforcement. This means that the task of the police is more directed to the way of cracking down on perpetrators who break the rules. According to Act No. 2 of 2002 concerning the Indonesian National Police, the police institution is a state institution that is given certain tasks, functions and authorities to maintain security, order and protect the public.

Law enforcement according to the regional regulation number 12 of 2004 concerning the prohibition on the distribution of alcoholic drinks in Kudus is carried out by the Regent who is assisted by the supervisory and control team as referred to in Article 3 . In law enforcement has increased raids and supervision of illegal distribution of alcoholic beverages, however the operating business is expected to continue running consistently In carrying out law enforcement, coordination is needed so that the cooperation and capabilities of the Kudus Police District and the Kudus government are strengthened to increase harmony, smoothness, efficiency, and effectiveness in carrying out tasks in carrying out supervision of the selling places for White Alcohol beverages, which are indicated to have committed irregularities. The results of the interview by the Head of the Bin Sab Ops Sat Sabhara Kudus Police District Deni Dwi Noviandi, SH, MH and the Tipidsus Unit of the Kudus Police District Jajang Wiwoko., $\mathrm{SH}, \mathrm{MH}^{3}$

According to the Head of the Sat Sabhara Police Headquarters, Kudus Police, Deni Dwi Noviandi, $\mathrm{SH}, \mathrm{MH}$, in addition to the task of the Civil Service Police, the enforcement of regional legislation / regional regulations was also part of the duties of his unit. The implementation is in the form of an operation which is usually carried out every two weeks or according to complaints from the community and according to a letter of assignment from the Police Chief. " So far his side has been operating in places that are

\footnotetext{
${ }^{3}$ Results of the Interview on January 21, 2020 Kaur Bin Ops Sat Sabhara Holy Police Station Deni Dwi Noviandi, SH, MH and Kanit Tipidsus Kudus Police Jajang Wiwoko., SH, MH.
} 
vulnerable to the free circulation of alcohol, as well as places that are indicated to be circulating more mixed liquor which had previously been the target of operations.

In the implementation of the Kudus Police District referring to a warrant issued by the Chief of Police so that there is no imbalance of authority, where in the operation it holds a letter which as a strong basis for conducting operations. Every warrant operation is always changing. The result of the operation was a lot of mixed liquor confiscated as evidence. Illegal liquor also varies, there are alcoholic drinks which do not have excise, and there are alcoholic drinks, whiteness or op-penetration made by the people themselves. Not a few pieces of evidence were seized in the results of the operation. Evidence will be stored and will be destroyed in front of all parties related to the joint operation and carried out in the district prosecutor's office in Kudus, usually carried out at the time of commemorating Eid al-Fitr and the turn of the new year.

\subsection{Criminal Accountability Against Criminal Actors Producing and Selling "White Alcohol/White Liquor" Beverages in the Kudus Police District Region}

The theory used to analyze the problems in this thesis is the theory of criminal liability from Roeslan Saleh. Criminal liability is an act that is despicable by the community that must be accounted for by the creator for the act committed. By taking responsibility for that despicable act, is the maker also condemned or the maker is not condemned. Whereas the first one is of course the criminal convicted, whereas in the second case the maker of course. ${ }^{4}$

According to Roeslan Saleh, in the sense of criminal acts do not include accountability. Criminal acts according to Roeslan Saleh said, people who commit criminal acts and indeed have errors are the basis of criminal liability. The unwritten principle says, "there is no criminal if there is no error," is the basis of the creator's penalty. ${ }^{5}$

Someone makes a mistake, according to Prodjohamidjojo, if at the time of doing a delict, seen in terms of society it should be denounced. ${ }^{6}$

Thus, according to him, a person gets a criminal depends on two things, viz.

- There must be actions that are against the law, or in other words, there must be elements against the law. So there must be a subjective element, and

- With regard to the perpetrators there is an element of error in the form of deliberate and / or negligence, so that acts that violate the law can be accounted for.

In this case there has been a criminal offense of goods who sell, offer, surrender or distribute goods which are known to endanger the lives or health of people while the dangerous nature is not notified, business actors are prohibited from producing and or trading goods that do not include an expiration date and do not put labels, food businesses who intentionally do not have a marketing authorization for any processed food made domestically or imported for trade in retail packaging, business actors carrying out business activities of trade granted by the Minister as referred to in article

\footnotetext{
${ }^{4}$ Roeslan Saleh. 1982. Pikiran-pikiran Tentang Pertanggungjawaban Pidana. Ghalia Indonesia. Jakarta. p. 75-76

${ }^{5}$ DjokoPrakoso, 1987, Asas-asas Hukum Pidana di Indonesia. First Edition, Liberty Yogyakarta, Yogyakarta, p. 75.

6 Prodjohamidjojo, Martiman, 1997, Memahami dasar dasar hukum Pidana Indoesia,: PT. PradnyaParamita, Jakarta, p.31
} 
204 paragraph (1) of the Indonesian Criminal Code and Article 142 of Act No. 18 of 2012 Regarding Food occurring on Monday, April 16, 2018, approximately 14.00 WIB in the warehouse where the production of White Alcohol beverages with the address at Prambat Lor Village RT: 007 RW: 003 Kaliwungu District Kudus District, allegedly committed by HUDA WILDANY Bin TAUFIQ JUANAIDI, 24 years old, was born in Kudus, the perpetrators were making or producing and producing and producing and distributing white liquor called White Alcohol which runs for about 2 months with daily turnover 50 boxes for 1 cardboard box containing 12 bottles with 1.5 liter bottle size then the Kudus Resort Police officers capture and secure evidence then the Kudus police officers arresting and securing evidence and then being taken to the Kudus police chief for investigation. Allegedly committed by suspect HUDA WILDANY Bin TAUFIQ JUANAIDI, 24 years old, born in Kudus, the perpetrator is making or producing and distributing white liquor or called White Alcohol that runs for about 2 months with daily turnover of 50 boxes for 1 cardboard containing 12 bottles with a 1.5 liter bottle size then the Kudus Resort Police officer captures and secures the evidence then the Kudus police police officer captures and secures the evidence then the sacred police chief is brought in to investigate. Allegedly committed by suspect HUDA WILDANY Bin TAUFIQ JUANAIDI, 24 years old, born in Kudus, the perpetrator is making or producing and distributing white liquor or called White Alcohol that runs for about 2 months with daily turnover of 50 boxes for 1 cardboard containing 12 bottles with a 1.5 liter bottle size then the Kudus Resort Police officer captures and secures the evidence then the Kudus police police officer captures and secures the evidence then the sacred police chief is brought in to investigate. The perpetrator is making or producing and distributing white liquor or called White Alcohol which runs for about 2 months with daily turnover 50 boxes for 1 cardboard box containing 12 bottles with 1.5 liter bottle size and then the Kudus Resort Police officers capture and secure the goods evidence then the police of the Kudus police station did arrest and secure the evidence and then brought the Kudus police chief to be carried out the investigation process.the perpetrator is making or producing and distributing white liquor or called White Alcohol which runs for about 2 months with daily turnover 50 boxes for 1 cardboard box containing 12 bottles with 1.5 liter bottle size and then the Kudus Resort Police officers capture and secure the goods evidence then the police of the Kudus police station did arrest and secure the evidence and then brought the Kudus police chief to be carried out the investigation process.

\section{Closing}

\subsection{Conclusion}

- There are 2 (two) ways of law enforcement on the circulation of alcohol by the Kudus Police District, namely preventive and repressive. Preventive action is taken if possible and there is still public awareness to obey the law. Whereas repressive actions are actions taken if preventive measures are not effective, so that people implement the law even if forced. While the police in law enforcement there are (two) actions, namely persuasive actions and repressive actions which have their own objectives. In persuasive action the police take precautions which often conduct counseling, provide guidance to the public about the dangers of alcohol. While the 
police repressive actions carry out investigations, searches, and arrests if there is an indication of the crime of the circulation of alcohol.

- Criminal accountability against criminal offenders producing and selling "White Alcohol drinks / impurities" that will come in the renewal of Indonesian criminal, Criminal policy against alcoholic drinks in Indonesia has been regulated in accordance with the provisions in the Criminal Code, Minister of Trade Regulations and Regulations at the regional level / By law The proposed Bill on the Prohibition of Alcoholic Beverages regulates a strict ban on all alcoholic drinks in Indonesia. This tends to cause new problems, especially the loss of the ability of the state to control and control the circulation of alcohol. The bill should regulate efforts to control and supervise the production, marketing and consumption of alcoholic beverages, price control,

\subsection{Suggestion}

- The Kudus Police party should conduct raids spontaneously so that leakage of information about the conduct of raids does not spread first in the community so that naughty parties who commit criminal acts of alcohol cannot eliminate evidence and need an active role from the community in eradicating the circulation of alcohol in the type of White Alcohol / White Liquor.

- Revise regional regulations on alcoholic drinks in Kudus, especially on sanctions contained in these regional regulations so that they are more severe and strict because in practice there are still many who repeat the circulation of alcoholic beverages despite being given a fine and probation, while waiting the ratification of the Draft Bill on Alcoholic Beverages.

\section{References}

[1] Andi Hamzah, 2001, Asas-Asas Hukum Pidana, Rineka Cipta, Jakarta

[2] Bambang Sunggono, 2003, Metode Penelitian hukum, PT Raja Grafindo Persada, Jakarta

[3] Barda Nawawi Arief, 2002, Kebijakan Hukum Pidana, PT. Citra Aditya Bakti, Bandung

[4] Hartati Nurwijaya, 2009, Bahaya alkohol dan cara pencegahannya, PT Elex Media Kompitind, Jakarta

[5] Mardjono Reksodipuro, 1999. Kriminologi dan Sistem Peradilan Pidana Kumpulan Karangan Buku Kedua, Center for Justice and Legal Service Services Criminology Institute, University of Indonesia, Jakarta

[6] Muladi, Democratization, 2002, Hukum dan Hak Asasi Manusia, dan Reformasi Hukum di Indonesia, The Habibie Center, Jakarta

[7] Mulyana W. Kusumah, 2001, Tegaknya Supermasi Hukum, PT. Rosdakarya, Bandung

[8] Moeljatno, 2002, Perbuatan Pidana dan Pertanggungjawaban Dalam Hukum Pidana, Bina Aksara, Yogyakarta

[9] Rahardjo, Satjipto, 1983, Masalah Penegakan Hukum; Suatu Tinjauan Sosiologis, National Legal Development Agency, Ministry of Justice, Jakarta 